\title{
Influence of Machining Parameter on Tool Life While Machining Hybrid Metal Matrix Composites
}

\author{
C. R. Prakash Rao' ${ }^{*}$, V. Ravi Kumar ${ }^{1}$, D. V. Ravi Kumar ${ }^{1}$, Poorna Chandra ${ }^{1}$, M. Vedavyasa', \\ M. S. Rajagopal ${ }^{2}$
}

${ }^{1}$ Department of Mechanical Engineering, Global Academy of Technology, Bengaluru, India

${ }^{2}$ Department of Mechanical Engineering, Dayananda Sagar University, Bangalore, India

Email: * prakashraocr2015@gmail.com

How to cite this paper: Rao, C.R.P., Kumar, V.R., Kumar, D.V.R., Chandra, P., Vedavyasa, M. and Rajagopal, M.S. (2020) Influence of Machining Parameter on Tool Life While Machining Hybrid Metal Matrix Composites. Journal of Minerals and Materials Characterization and Engineering, 8, 440-458.

https://doi.org/10.4236/jmmce.2020.86028

Received: August 28, 2020

Accepted: November 3, 2020

Published: November 6, 2020

Copyright $\odot 2020$ by author(s) and Scientific Research Publishing Inc. This work is licensed under the Creative Commons Attribution International License (CC BY 4.0).

http://creativecommons.org/licenses/by/4.0/

\begin{abstract}
A metal matrix composite constitutes a continuous metallic matrix and a discontinuous phase known as reinforcement. The hybrid metal matrix composites (Hmmcs) have been used to manufacture drive shafts, disc brake rotors, brake drums, connecting rods pistons, engine block cylinder liners for automotive and rail vehicle applications. The Hmmcs castings of diameter $120 \mathrm{~mm}$ and length $300 \mathrm{~mm}$ were prepared through sand mould technique following stir casting methodology. The cast components further subjected to evaluation of physical properties and machining tests using two grades of coated inserts and PCD inserts. The experiments were carried out following ISO 3685 standards. The coating thickness of the TiN coated and TiAlN coated inserts were measured using Kalo testing method; the results of the test show that the interface of the substrate and coating was free from the porosity, and the coating thickness of TiN coating was 4.84 microns and TiAlN coating was measured 4.6 microns. The results of the experiments show that performance of the PCD insert was better than coated inserts at $0.1 \mathrm{~mm} / \mathrm{rev}$ feed; however at $0.2 \mathrm{~mm} /$ revolution feed PCD insert failed by micro chipping of cutting edge while machining Hmmcs. When TiAlN coated inserts were used to machine Hmmcs the coated inserts failed by gradual wear and BUE formation.
\end{abstract}

\section{Keywords}

Composites, Hybrid Metal Matrix Composites, Coated Inserts, PCD Inserts, Turning, Tool Life Testing 


\section{Introduction}

Advanced materials are possessing excellent physical and mechanical properties having higher wear resistance are preferred for automobile, aviation and machine building applications. The aluminium matrix composites which are of lower density and higher performance tailored cast materials [1] [2] [3]. Aluminum alloy is preferred in aerospace application, owing to its properties such as high specific stiffness, specific strength and ease with which it can be fabricated [4]. The aluminum alloys will cover a wide usage in the areas such as subzero temperature, moderate and elevated temperature range applications [5]. The mmcs containing $5 \mathrm{wt} \%$ and $7 \mathrm{wt} \%$ reinforcement of $\mathrm{B}_{4} \mathrm{C}$ particles are casted at $750^{\circ} \mathrm{C}$ temperature following stir cast method incorporating two-step additions [6]. The composites possess huge potential since, composites can be tailored to meet the requirements of the end user; however, the use of the composites is limited owing to increased manufacturing cost which is due to the specialized processing methods followed in the fabrication of the composites [7] [8] [9] [10] [11]. The aluminum alloy can be fabricated using different reinforcements such as silicon carbide, fly ash, cenosphere, graphite [12] [13] [14] [15]. The increased hardness of the $\mathrm{Al}_{2} \mathrm{O}_{3}$ and $\mathrm{SiC}$ particles significantly enhances wear resistance of the composite material and hence affects machinability [16] [17] [18] [19] [20]. However, use of the coated inserts reduces too wear and hence increases productivity [21] [22] [23]. Further, use of PCD inserts results superior surface texture and increases productivity [24] [25].

The above review revealed that a limited number of research works was done on the study of machinability pertaining to aluminum Hmmcs composites. The aim of the research work is therefore to investigate the influence of machining parameter on tool life using coated carbide inserts and PCD insert during turning of aluminum Hmmcs composites at varied cutting speed and feed using single point cutting tool.

\section{Experimental Details}

The details of materials used to carry out the research work and the methods followed to carry out machinability study are briefly discussed in this part. The details of hybrid composite material fabrication and stir casting methodology are also described.

\subsection{Work Materials}

The matrix material used for the research work was Al6061 grade aluminum alloy. Figure 1 shows the Al6061 ingots used for the preparation of the composite. Table 1 and Table 2 show the physical and mechanical properties and also chemical composition of Al6061 grade aluminum alloy respectively.

\subsection{Reinforcement}

The Reinforcements used to fabricate hybrid metal matrix composites are flyash 
(FA), silicon carbide ( $\mathrm{SiC}$ ) and graphite (Gr) particles. The FA contains mainly silica and alumina with minor amounts of iron, potassium and magnesium oxides as revealed by the chemical composition analysis. Table 3 and Table 4 show the physical properties and chemical composition of FA respectively. The chemical composition of the $\mathrm{SiC}$ particles is presented in Table 5. The density of the $\mathrm{Gr}$ measures $2.26 \mathrm{~g} / \mathrm{cm}^{3}$. The $\mathrm{Gr}$ contains mainly carbon as revealed by the chemical composition analysis. Table 3 and Table 6 show the physical properties and chemical composition of Gr respectively.

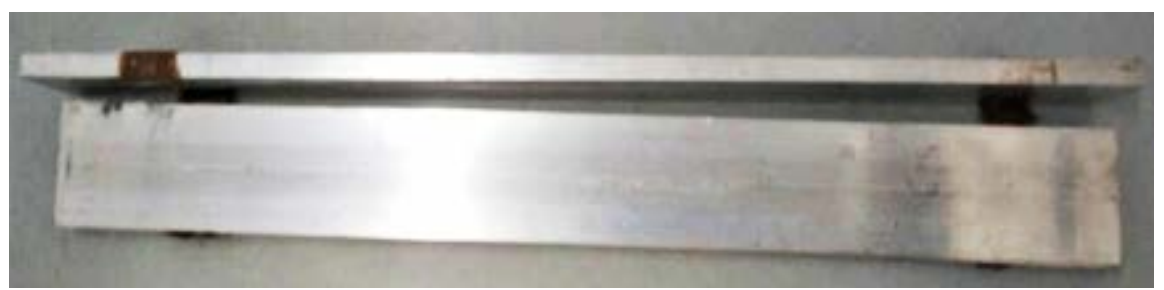

Figure 1. Al6061 ingot.

Table 1. Properties of Al6061.

\begin{tabular}{cc}
\hline Physical Properties & Value \\
\hline Density $(\mathrm{g} / \mathrm{cc})$ & 2.70 \\
Melting Point $\left({ }^{\circ} \mathrm{C}\right)$ & 670 \\
Hardness $(\mathrm{BHN})$ & 56 \\
\hline
\end{tabular}

Table 2. Chemical composition of Al6061.

\begin{tabular}{cccccc}
\hline Chemical composition & $\mathrm{Mg}$ & $\mathrm{Si}$ & $\mathrm{Cu}$ & $\mathrm{Fe}$ & $\mathrm{Al}$ \\
\hline Wt\% & 0.848 & 0.665 & 0.251 & 0.185 & Balance \\
\hline
\end{tabular}

Table 3. Physical properties of reinforcement.

\begin{tabular}{cccc}
\hline Physical Properties & FA & SiC & Gr \\
\hline Density $(\mathrm{g} / \mathrm{cc})$ & 1.74 & 3.16 & 2.26 \\
Melting Temperature $\left({ }^{\circ} \mathrm{C}\right)$ & 1200 & 2730 & 3600 \\
Hardness (Mohs scale) & 7 & $9-9.5$ & $1-2$ \\
\hline
\end{tabular}

Table 4. Chemical composition of flyash.

\begin{tabular}{ccccccccc}
\hline Parameter & $\mathrm{SiO}_{2}$ & $\mathrm{Al}_{2} \mathrm{O}_{3}$ & $\mathrm{CaO}$ & $\mathrm{MgO}$ & $\mathrm{Fe}_{2} \mathrm{O}_{3}$ & $\mathrm{SO}_{3}$ & $\mathrm{Na}_{2} \mathrm{O}$ & $\mathrm{K}_{2} \mathrm{O}$ \\
\hline $\mathrm{Wt} \%$ & 53.2 & 26.43 & 4.69 & 1.20 & 3.07 & 0.63 & 0.22 & 0.94 \\
\hline
\end{tabular}

Table 5. Chemical composition of SiC.

\begin{tabular}{ccccccccc}
\hline Parameter & $\mathrm{Si}$ & $\mathrm{C}$ & $\mathrm{Al}$ & $\mathrm{Mg}$ & $\mathrm{Fe}$ & $\mathrm{Ca}$ & $\mathrm{P}$ & $\mathrm{S}$ \\
\hline $\mathrm{Wt} \%$ & 62.0 & 26.50 & 2.50 & 0.25 & 0.56 & 0.60 & 0.005 & 0.006 \\
\hline
\end{tabular}


Table 6. Chemical composition of graphite.

\begin{tabular}{ccccccc}
\hline Parameter & $\mathrm{C}$ & $\mathrm{SiO}_{2}$ & $\mathrm{Al}_{2} \mathrm{O}_{3}$ & $\mathrm{MgO}$ & $\mathrm{Fe}_{2} \mathrm{O}_{3}$ & $\mathrm{CaO}$ \\
\hline $\mathrm{Wt} \%$ & 77.83 & 10.10 & 1.5 & 0.32 & 0.4 & 0.30 \\
\hline
\end{tabular}

\subsection{Preparation of Composite Material}

The Al6061 Hmmcs reinforced with FA, SiC and Gr were fabricated using liquid metallurgy route. The matrix material was melted using stir casting process at a controlled temperature and the desired quantity of reinforcements was added to the molten aluminum alloy.

The molten aluminum alloy and reinforcements were stirred continuously to create a vortex to force the reinforcement particles in to the melt as shown in Figure 2. Stirring continued to disperse the reinforcement particles as uniformly as possible.

\subsection{Hardness Measurement of Work Material}

The Hardness measurement of newly fabricated Al6061-FA, SiC and Gr particles reinforced Hmmcs was carried out on Brinell hardness tester following ASTM standards. The Brinell hardness tester is shown in Figure 3. The specification of Brinell hardness tester is presented in Table 7.

The experimental results pertaining to the influence of reinforcement on the hardness of the Al6061 grade aluminum reinforced with FA, SiC and Gr particles are presented in Table 8.

\subsection{Density of the Composites}

The density of the aluminum alloy of grade Al6061 and its composites containing $\mathrm{FA}, \mathrm{SiC}$ and $\mathrm{Gr}$ were measured following experimental technique and also calculated using Rule of mixtures. Further the density value of measured and theoretical are almost align with each other. Thus indicating the method adopted for the fabrication of the composite material is reliable. The density of the Hmmcs measured using experimental methodology and also calculated using RoM is presented in Table 9.

\subsection{Scanning Electron Microscopy}

Microstructural examination was carried out using Scanning electron microscopy to examine the microstructure of the samples at a much greater resolution. The Specification of TES CAN VEGA-3 LMU SEM is presented in Table 10.

\section{Machine Tool \& Cutting Tool}

\subsection{Machine Tool}

The machine tool used for the experiments was ACE designers make, Jobber XL CNC Lathe, and the machine is shown in Figure 4, and the specification of the CNC Lathe is presented in Table 11. 


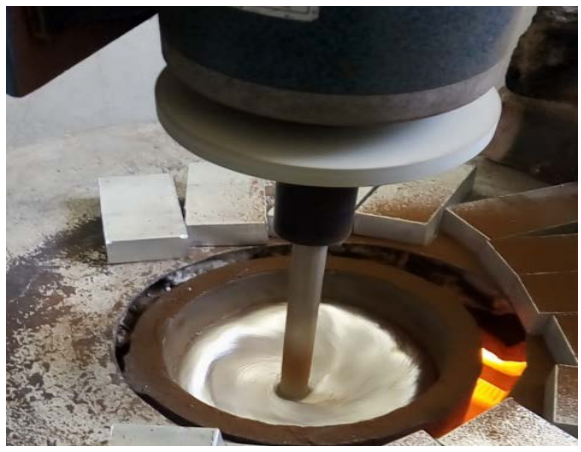

Figure 2. Stirring of hybrid composite material.

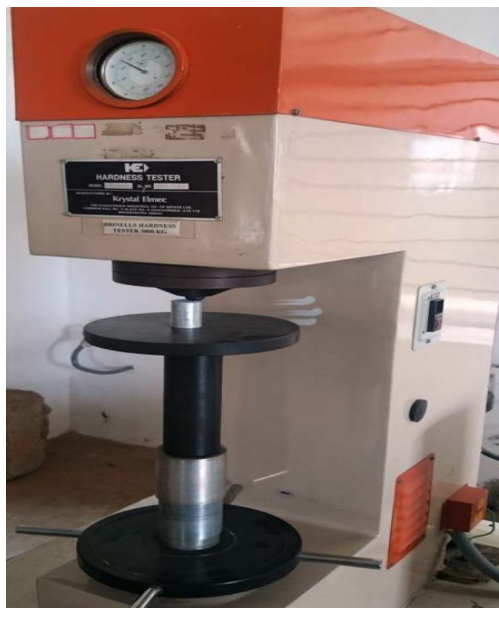

Figure 3. Conduction of hardness test on Brinell hardness testing machine.

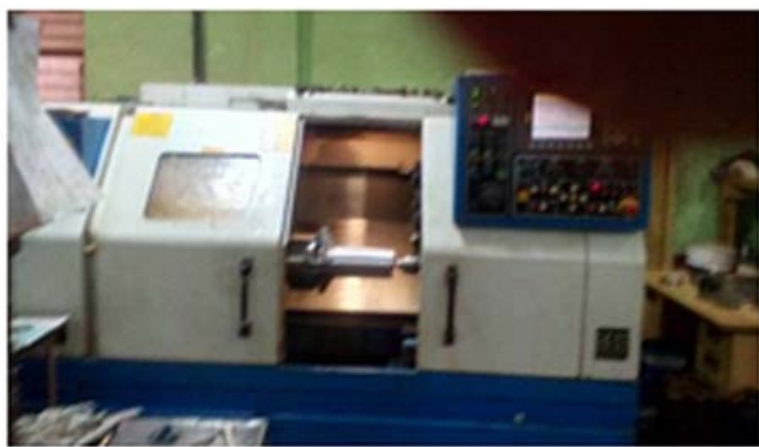

Figure 4. CNC machine used for the experiments.

Table 7. Specification of Brinell hardness tester.

\begin{tabular}{cc}
\hline Make & Krystal Elmec \\
Model & KB3000H \\
Range & 500 Kgs to $3000 \mathrm{Kgs}$ \\
Minor load & $500 \mathrm{Kgs}$ \\
Major load & $3000 \mathrm{Kgs}$ \\
Ball Indenter size & $10 \mathrm{~mm}$
\end{tabular}


Table 8. Hardness of the Al6061 grade aluminum alloy and its composites.

\begin{tabular}{ccc}
\hline Sample Designation & Reinforcement content & Hardness \\
\hline Sample 1 & Al6061 & 56.00 \\
Sample 2 & Al6061 + 3\% FA & 60.64 \\
Sample 3 & Al6061 + 3\% SiC & 76.56 \\
Sample 4 & Al6061 + 3\% Gr & 63.78 \\
Sample 5 & Al6061 + 3\% FA + 3\% SiC & 79.14 \\
Sample 6 & Al6061 + 3\% FA + 3\% Gr & 70.53 \\
Sample 7 & Al6061 + 3\% SiC + 3\% Gr & 73.77 \\
Sample 8 & Al6061 + 3\% FA + 3\% SiC + 3\% Gr & 81.27 \\
\hline
\end{tabular}

Table 9. Influence of reinforcement on density of the work material.

\begin{tabular}{cccc}
\hline Sample No. & Sample composition & $\begin{array}{c}\text { Theoretical } \\
\text { Density }(\mathrm{g} / \mathrm{cc})\end{array}$ & $\begin{array}{c}\text { Experimental } \\
\text { Density }(\mathrm{g} / \mathrm{cc})\end{array}$ \\
\hline Sample 1 & Al6061 & 2.7 & 2.7 \\
Sample 2 & Al6061 + 3\% FA & 2.6751 & 2.6812 \\
Sample 3 & Al6061 + 3\% SiC & 2.7139 & 2.7095 \\
Sample 4 & Al6061 + 3\% Gr & 2.6868 & 2.6796 \\
Sample 5 & Al6061 + 3\% FA + 3\% SiC & 2.6891 & 2.6803 \\
Sample 6 & Al6061 + 3\% FA + 3\% Gr & 2.6619 & 2.6622 \\
Sample 7 & Al6061 + 3\% SiC + 3\% Gr & 2.7011 & 2.696 \\
Sample 8 & Al6061 + 3\% FA + 3\% SiC + 3\% Gr & 2.6758 & 2.6674 \\
\hline
\end{tabular}

Table 10. Specification of Scanning Electron Microscopy (SEM).

$\begin{array}{cc}\text { Instrument Name } & \text { TES CAN VEGA-3 LMU } \\ \text { Made in } & \text { Czech Republic } \\ \text { SEM Magnification } & 4.5 \times \text { to } 1,000,000 \times \\ \text { SEM Resolution } & 3 \mathrm{~nm} \text { at } 30 \mathrm{kV} \\ \text { Maximum Field of View } & 0.08 \mu \mathrm{m} \\ \text { SEM HV (High Voltage) } & 5-30 \mathrm{kV} \\ \text { SEM WD (Working Distance) } & 1-40 \mathrm{~mm} \\ \text { Electron Gun } & \text { Tungsten Heated Cathode } \\ \text { Scanning Speed } & \text { From } 20 \text { ns to } 10 \mathrm{~ms} \text { per pixel }\end{array}$

Table 11. Specification of CNC Machine used for the experiments.

\begin{tabular}{cc}
\hline Maximum turning diameter & $270 \mathrm{~mm}$ \\
\hline Maximum machining length & $400 \mathrm{~mm}$ \\
Range of spindle speed & $50-4000 \mathrm{RPM}$ \\
Job clamping system & Hydraulic \\
Dimension of CNC lathe & $2200 \times 1750 \times 1750 \mathrm{in} \mathrm{mm}$ \\
\hline
\end{tabular}




\subsection{Cutting Tool}

The cutting tool used for conducting experiments was Kennametal make positive rake angle turning tool holder. The tool holder modified to obtain $10^{\circ}$ positive side rake angle. The nomenclature of the tool holder is tabulated in Table 12. The tool holder used for the experiments is shown in Figure 5.

\section{Results \& Discussion}

\subsection{Measurement of Coating Thickness}

The tungsten carbide inserts preferred for machining these Hmmcs are coated with hard and wear resistant thin layer of Titanium carbide, Titanium nitrate, aluminum oxide, aluminum nitrate, zirconium carbo nitrate so on, using either physical vapour deposition or chemical vapour deposition coating methods.

The quality of the coating is measured using various methods; one such method is subjecting the cutting tool surface to revolving spherical object, which leads to the formation of spherical dent on the surface of the cutting tool. By measuring the dent formed on the tool surface; the thickness of the coating applied on the cutting tool was measured. Figure 6 shows the cavity formed on the coated insert used for experiments. The coating thickness of the inserts is measured using the equation, Coating thickness $=\frac{x y}{2 R}$ in microns. Figure 6(a) shows the image of Kalo of TiN coated insert and Figure 6(b) shows the image of Kalo of TiAlN coated insert. The experimental results revealed that the coating thickness of the TiN coated insert used for the experiment was measured 4.84 microns and coating thickness of the TiAlN coated insert used for the experiment was measured 4.6 microns.

\subsection{Hardness Test}

Measurement of BHN was carried out following ASTM E10 standard. The measured hardness values of matrix, composite and hybrid composite materials are presented in Figure 7. From Figure 7, it can be inferred that, hardness of the Al6061 is lower than its composites.

Table 12. Nomenclature of the tool holder used for the experiments.

\begin{tabular}{cc}
\hline Description & Coated insert \\
\hline Back rake angle & $15^{\circ}$ \\
Side rake angle & $10^{\circ}$ \\
End cutting edge angle & $95^{\circ}$ \\
Side cutting edge angle & $95^{\circ}$ \\
End clearance angle & $15^{\circ}$ \\
Side clearance angle & $15^{\circ}$ \\
Cutting tool type & Throw away insert \\
\hline
\end{tabular}




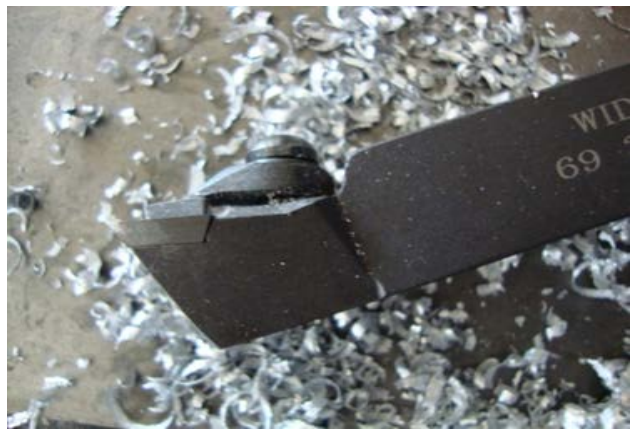

Figure 5. Tool holder used for the experiments.

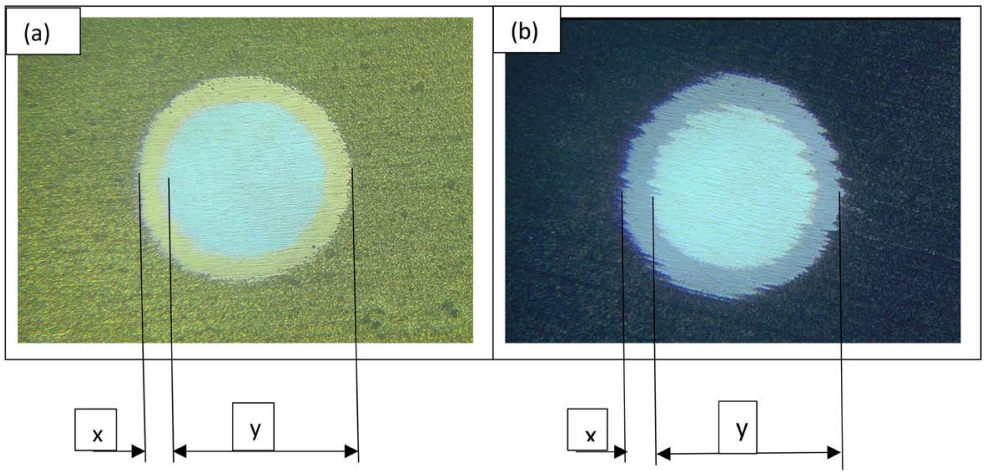

Figure 6. Cavity formed on the coated insert used for experiments.

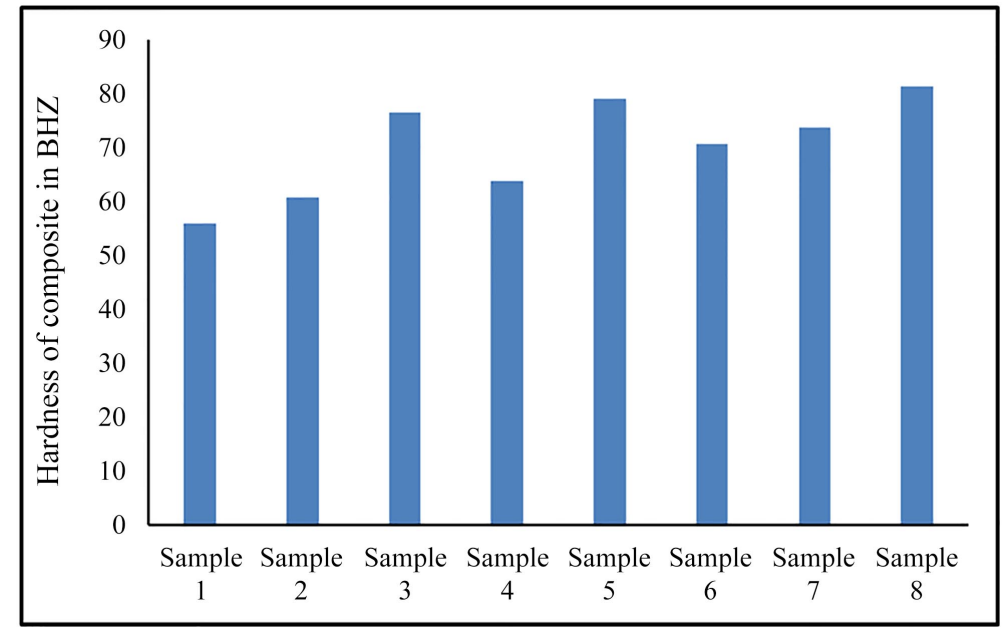

Figure 7. Influence of reinforcement on the hardness of Al6061 and its composites.

The hardness of the composite material having composition Al6061 + 3\% FA $+3 \% \mathrm{SiC}+3 \% \mathrm{Gr}$ measured highest, this may be the reason that hardness of Reinforcement content, that is $\mathrm{Al}_{2} \mathrm{O}_{3}, \mathrm{SiO}_{2}, \mathrm{Si}, \mathrm{C}$ and $\mathrm{Fe}_{2} \mathrm{O}_{3}$.

\subsection{Density}

Figure 8 shows the variation of density of the composite as a function of reinforcement.

From Figure 8, it can be observed that the density of the composite contain- 
ing FA and Gr reinforcements is lower than the density of the matrix material, however the composite material containing $\mathrm{SiC}$ is marginally higher than matrix material. It is attributed to the fact that the density of the FA and Gr reinforcements are lower than the matrix material and density of the $\mathrm{SiC}$ is marginally higher than that of matrix matrial. Further the density value of measured and theoretical are almost align with each other. Thus indicating the method adopted for the fabrication of the composite material is reliable.

\subsection{Micro Structural Analysis}

\subsubsection{SEM Analysis of Matrix Material \& Reinforcements}

Figure 9 shows the SEM microphotographs of the Al6061 grade aluminum alloy used for the experiments.

Figure 9 shows the SEM microphotographs of the reinforcements $\mathrm{FA}, \mathrm{SiC}$, Gr. From, Figure 9, it is evident that the average diameter of the reinforcements FA, SiC, Gr particles were mesured below 53 microns. Further, from SEM microphotographs, we can observe that the $\mathrm{FA}, \mathrm{SiC}, \mathrm{Gr}$ particles are almost uniform.

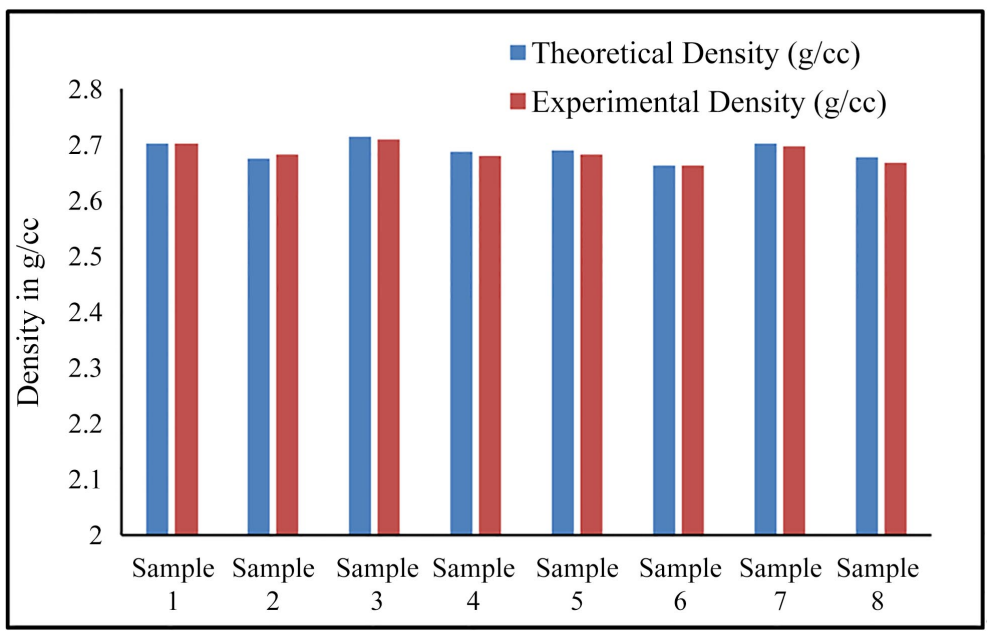

Figure 8. Influence of reinforcement on density.

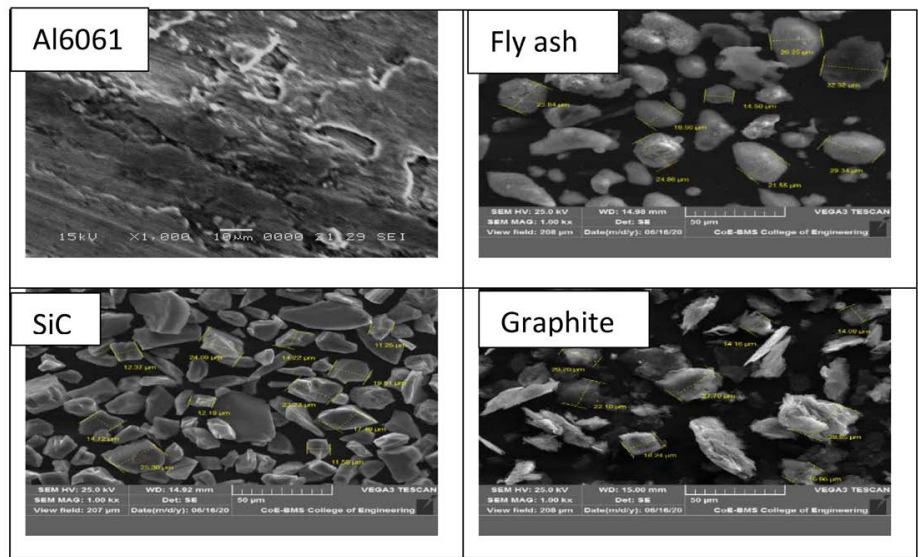

Figure 9. SEM microphotographs of matrix material-Al6061 \& Fly ash, SiC, Graphite Reinforcement particles. 


\subsubsection{SEM Analysis of Composite Material}

Distribution of the FA, SiC, Gr particles in the Al6061 matrix was verified using VEGA-3, TES CAN make SEM, and the microphotographs are shown in Figure 10. SEM analysis of cast composite material with different filler materials was examined using JEOL model JSM 6380 Scanning Electron Microscope. Figure 10 shows, SEM images of Al6061 matrix and Hmmcs composite material reinforced with FA, SiC \& Gr SEM analysis of the components indicate the uniform distribution of $\mathrm{FA}, \mathrm{SiC}$ and $\mathrm{Gr}$ particles in the aluminum matrix. SEM analysis reveals that, the morphological details of the $\mathrm{FA}, \mathrm{SiC}$, and $\mathrm{Gr}$ particles and also percent distribution in the matrix. The stir mixing method has resulted in the homogeneous distribution of $\mathrm{FA}, \mathrm{SiC}$ and $\mathrm{Gr}$ particles with minimum porosity in the Hmmcs composite material.

\subsubsection{Tool Life Test}

The tool life test of the composites containing varied combinations of reinforcements were carried out using coated carbide and PCD inserts of identical geometry. ISO 3685 standards were followed during continuous turning test. Dry machining maintaining 1.5 times shank size as tool over hang was maintained for test. The cutting speed and feed per revolution was varied during the experiment by keeping and depth of cut as constant. Continuous turning tests were conducted to access the tool life following alternate tool exchange method.

The combination of matrix \& reinforcement used for the turning test is tabulated in Table 13. The combination of machining parameter and insert used for the experiment is tabulated in Table 14 and the Tool life obtained during continuous turning is tabulated in Table 15 and Table 16. The tool life measured on the Al6061 casting, composite material and Hmmcs in continuous turning as a function of different $\mathrm{FA}, \mathrm{SiC}$, Gr at different cutting speed and feed was analysed in Figures 11-22.

Table 13. Combination of matrix \& reinforcement used for turning test.

\begin{tabular}{cc}
\hline Combination of Matrix \& Reinforcement & Sample title \\
Al6061 & Sample 1 \\
Aluminum $+3 \% \mathrm{FA}$ & Sample 2 \\
Aluminum $+3 \% \mathrm{SiC}$ & Sample 3 \\
Aluminum $+3 \% \mathrm{FA}+3 \% \mathrm{SiC}$ & Sample 4 \\
Aluminum $+3 \% \mathrm{FA}+3 \% \mathrm{Gr}$ & Sample 5 \\
Aluminum $+3 \% \mathrm{SiC}+3 \% \mathrm{Gr}$ & Sample 6 \\
Aluminum $+3 \% \mathrm{FA}+3 \% \mathrm{SiC}+3 \% \mathrm{Gr}$ & Sample 7 \\
\hline
\end{tabular}


Table 14. Combination of machining parameter and insert used for experiment.

\begin{tabular}{cccc}
\hline & Type of insert & Cutting speed & Feed \\
\hline Machining parameter 1 (MP1) & TiAlN Coated & $300 \mathrm{~m} / \mathrm{min}$ & $0.1 \mathrm{~mm} / \mathrm{rev}$. \\
Machining parameter 2 (MP2) & TiAlN Coated & $400 \mathrm{~m} / \mathrm{min}$ & $0.1 \mathrm{~mm} / \mathrm{rev}$. \\
Machining parameter 3 (MP3) & TiAlN Coated & $500 \mathrm{~m} / \mathrm{min}$ & $0.1 \mathrm{~mm} / \mathrm{rev}$. \\
Machining parameter 4 (MP4) & TiN Coated & $300 \mathrm{~m} / \mathrm{min}$ & $0.1 \mathrm{~mm} / \mathrm{rev}$. \\
Machining parameter 5 (MP5) & TiN Coated & $400 \mathrm{~m} / \mathrm{min}$ & $0.1 \mathrm{~mm} / \mathrm{rev}$. \\
Machining parameter 6 (MP6) & TiN Coated & $500 \mathrm{~m} / \mathrm{min}$ & $0.1 \mathrm{~mm} / \mathrm{rev}$. \\
Machining parameter 7 (MP7) & PCD & $300 \mathrm{~m} / \mathrm{min}$ & $0.1 \mathrm{~mm} / \mathrm{rev}$. \\
Machining parameter 8 (MP8) & PCD & $400 \mathrm{~m} / \mathrm{min}$ & $0.1 \mathrm{~mm} / \mathrm{rev}$. \\
Machining parameter 9 (MP9) & PCD & $500 \mathrm{~m} / \mathrm{min}$ & $0.1 \mathrm{~mm} / \mathrm{rev}$. \\
\hline
\end{tabular}

Table 15. Tool life in minutes during continuous turning test at $0.1 \mathrm{~mm}$ feed per revolution.

\begin{tabular}{lccccccccc}
\hline & MP1 & MP2 & MP3 & MP4 & MP5 & MP6 & MP7 & MP8 & MP9 \\
\hline Sample 1 & 48.9 & 35.41 & 18.86 & 41.25 & 27.44 & 15.86 & 76.41 & 58.63 & 30.47 \\
Sample 2 & 39.93 & 28.75 & 15.64 & 32.77 & 23.01 & 13.32 & 61.88 & 47.06 & 24.65 \\
Sample 3 & 26.15 & 24.11 & 12.86 & 24.61 & 18.68 & 10.25 & 49.64 & 38.99 & 19.16 \\
Sample 4 & 39.42 & 29.63 & 15.55 & 33.41 & 22.56 & 14.14 & 60.69 & 47.97 & 25.24 \\
Sample 5 & 27.33 & 21.88 & 14.02 & 23.56 & 15.74 & 13.73 & 44.26 & 36.15 & 23.31 \\
Sample 6 & 28.64 & 23.2 & 14.96 & 24.33 & 16.23 & 14.19 & 45.12 & 37.66 & 21.77 \\
Sample 7 & 25.12 & 20.17 & 13.58 & 24.17 & 15.78 & 12.01 & 41.86 & 32.37 & 20.15 \\
Hmmcs & 23.59 & 19.36 & 12.14 & 22.66 & 14.15 & 11.74 & 40.11 & 31.19 & 19.33 \\
\hline
\end{tabular}

Table 16. Tool life in minutes during continuous turning test at $0.2 \mathrm{~mm}$ feed per revolution.

\begin{tabular}{cccccccccc}
\hline & MP1 & MP2 & MP3 & MP4 & MP5 & MP6 & MP7 & MP8 & MP9 \\
\hline Sample 1 & 30.56 & 22.13 & 12.57 & 27.14 & 17.36 & 10.23 & 48.98 & 37.34 & 22.76 \\
Sample 2 & 24.8 & 17.96 & 10.42 & 21.24 & 14.84 & 9.18 & 41.25 & 29.74 & 15.70 \\
Sample 3 & 16.44 & 15.25 & 8.24 & 15.98 & 12.28 & 6.83 & 32.51 & 25.39 & 12.44 \\
Sample 4 & 25.31 & 18.87 & 10.23 & 21.56 & 14.94 & 9.34 & 39.42 & 31.14 & 16.74 \\
Sample 5 & 17.08 & 13.68 & 9.16 & 15.2 & 11.49 & 10.22 & 29.11 & 22.87 & 15.13 \\
Sample 6 & 17.88 & 14.82 & 9.65 & 15.89 & 10.54 & 9.38 & 29.68 & 24.94 & 13.95 \\
Sample 7 & 16.24 & 13.29 & 8.82 & 15.59 & 10.44 & 8.76 & 27.18 & 21.43 & 13.1 \\
Hmmcs & 14.21 & 12.1 & 7.44 & 13.23 & 8.75 & 7.25 & 24.77 & 19.28 & 11.59 \\
\hline
\end{tabular}




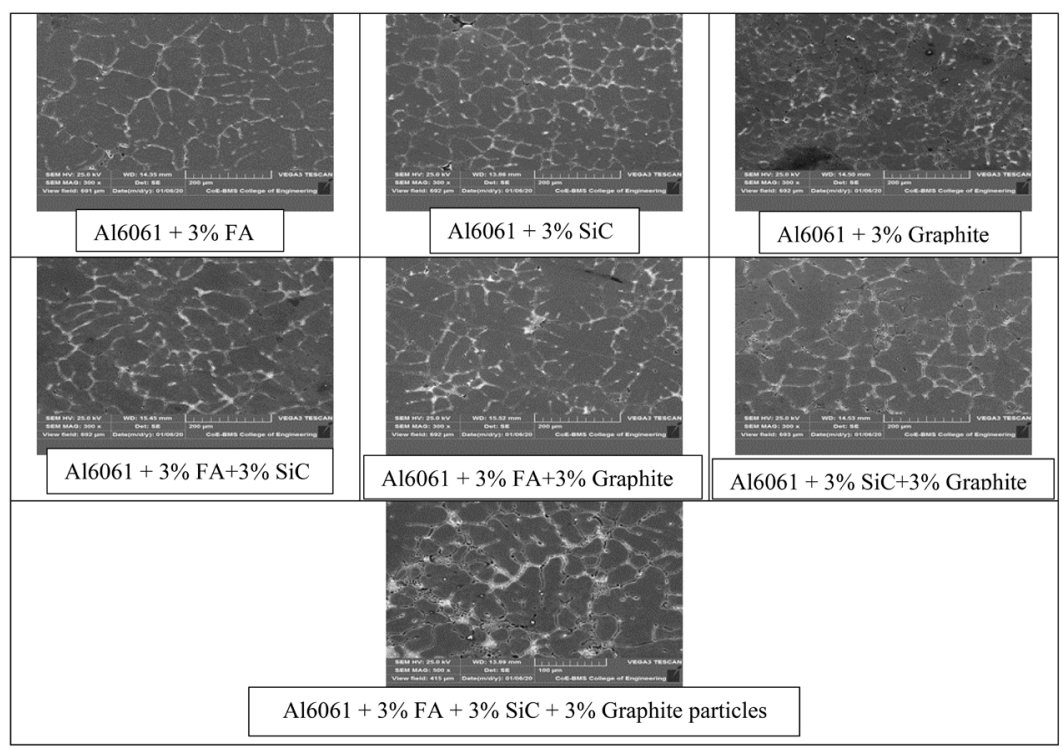

Figure 10. SEM microphotographs of metal matrix composite \& hybrid metal matrix composite material.

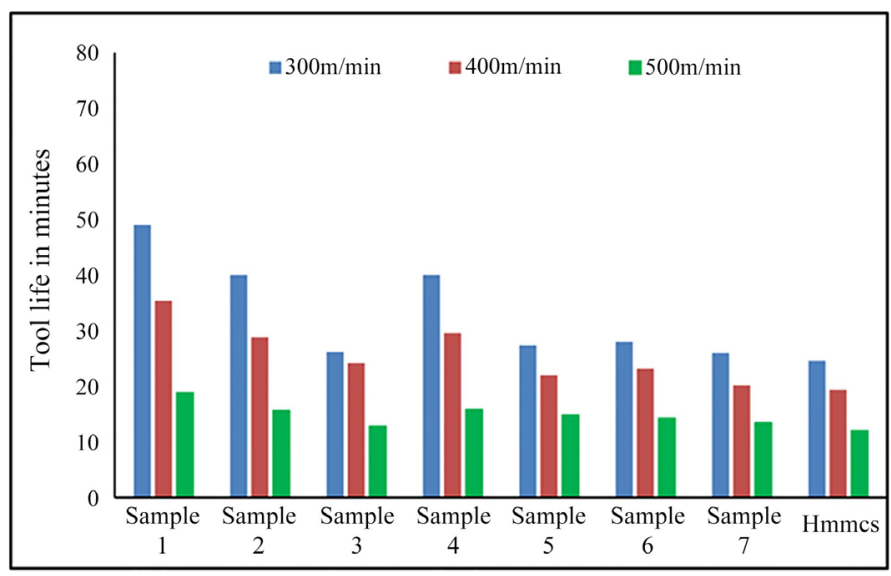

Figure 11. Effect of cutting speed on tool life using TiAlN coated carbide insert at $0.1 \mathrm{~mm} /$ revolution.

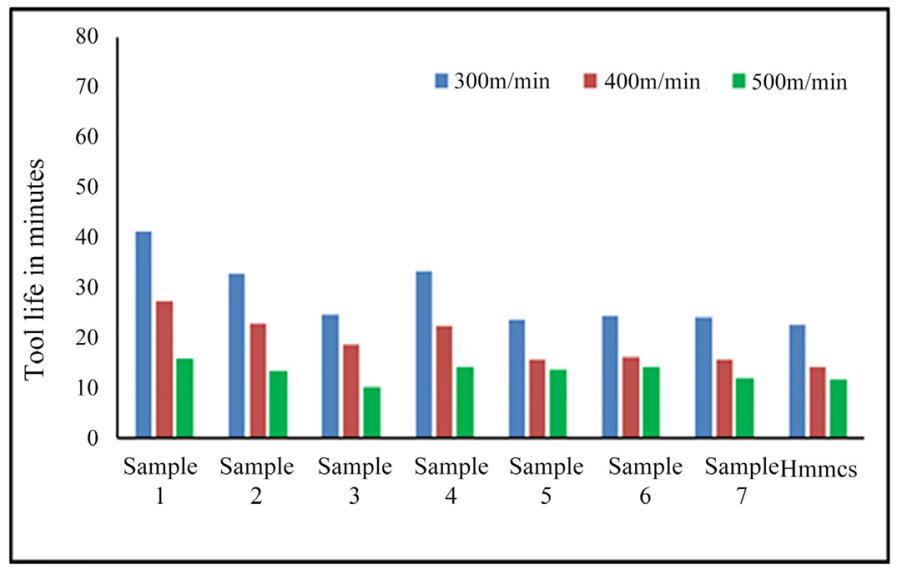

Figure 12. Effect of cutting speed on tool life using TiN coated carbide insert at $0.1 \mathrm{~mm} /$ revolution. 


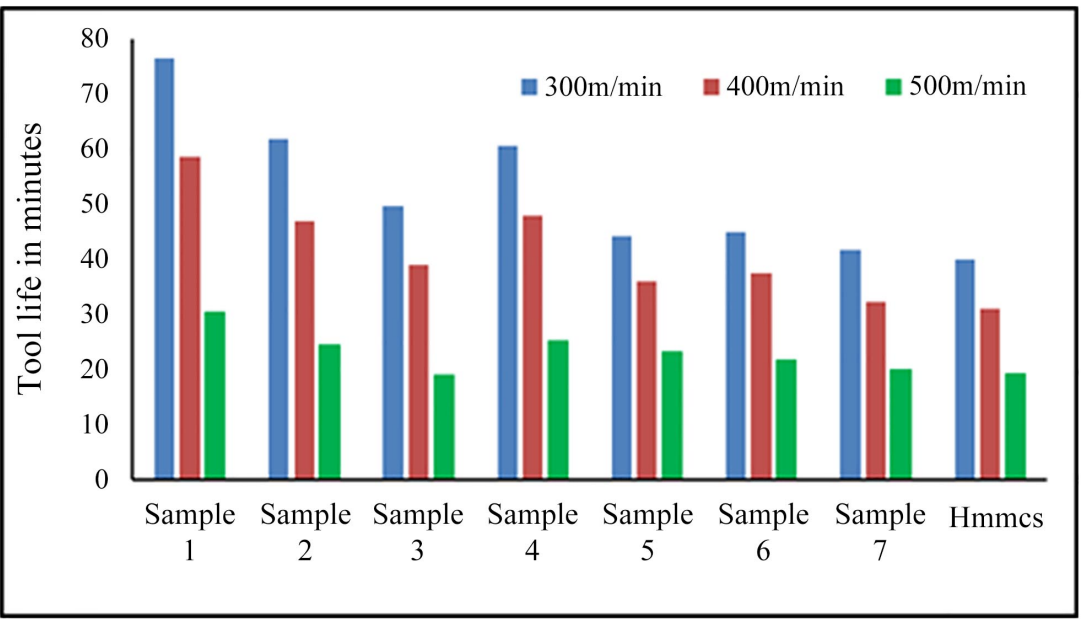

Figure 13. Effect of cutting speed on tool life using PCD insert at $0.1 \mathrm{~mm} /$ revolution.

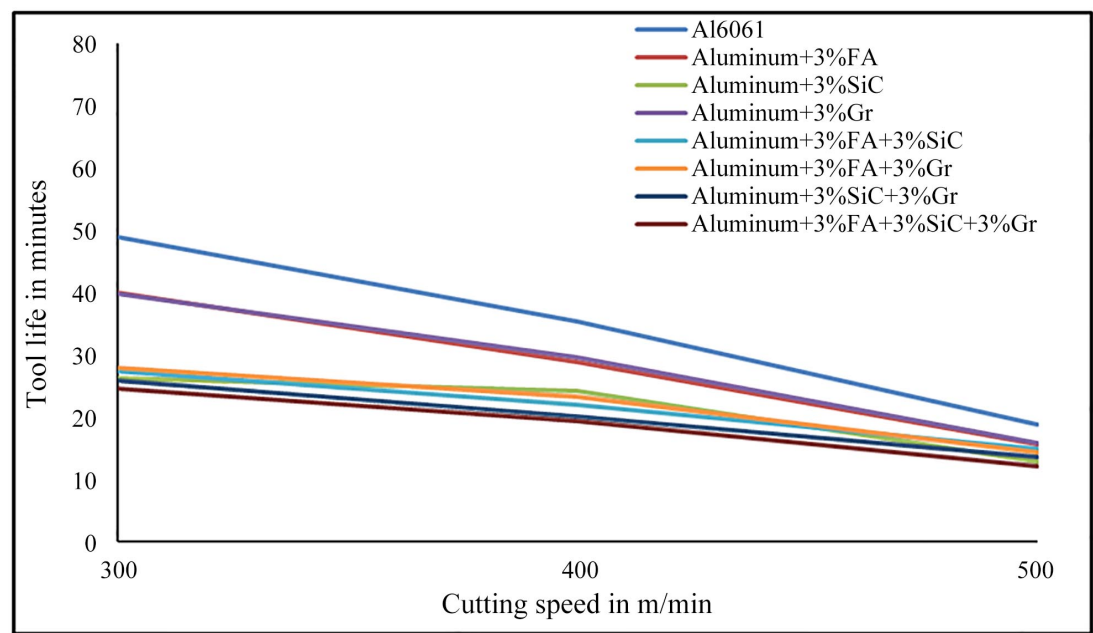

Figure 14. Effect of cutting speed and reinforcement on tool life using TiAlN coated carbide insert at $0.1 \mathrm{~mm} /$ revolution.

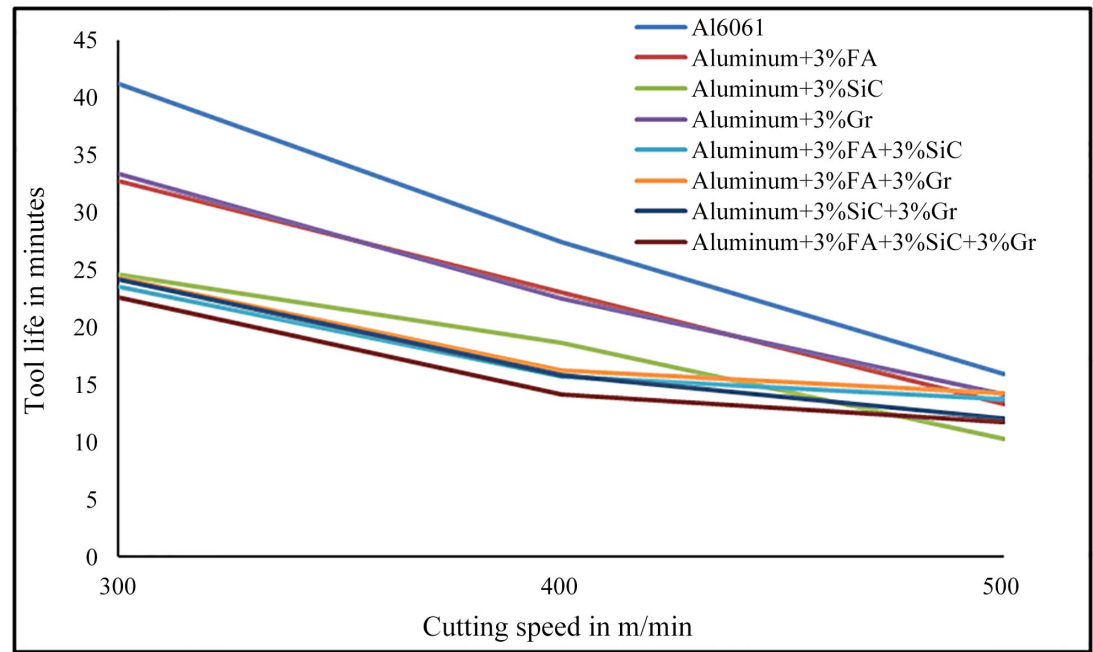

Figure 15. Effect of cutting speed and reinforcement on tool life using TiN coated carbide insert at $0.1 \mathrm{~mm} /$ revolution. 


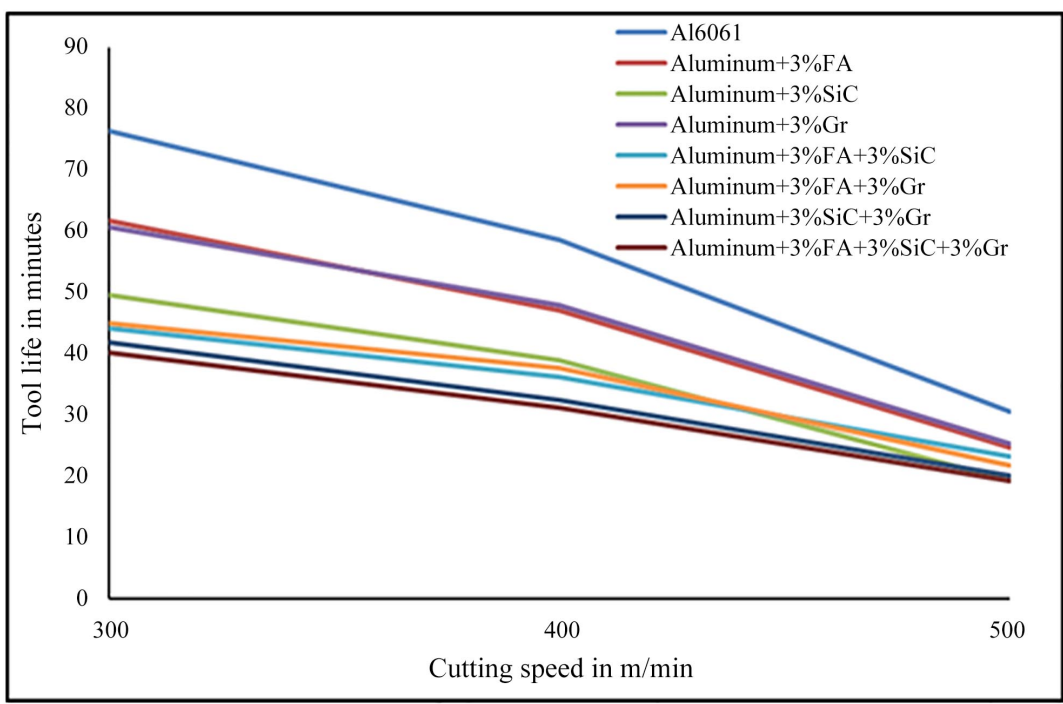

Figure 16. Effect of cutting speed and reinforcement on tool life using PCD insert at $0.1 \mathrm{~mm} /$ revolution.

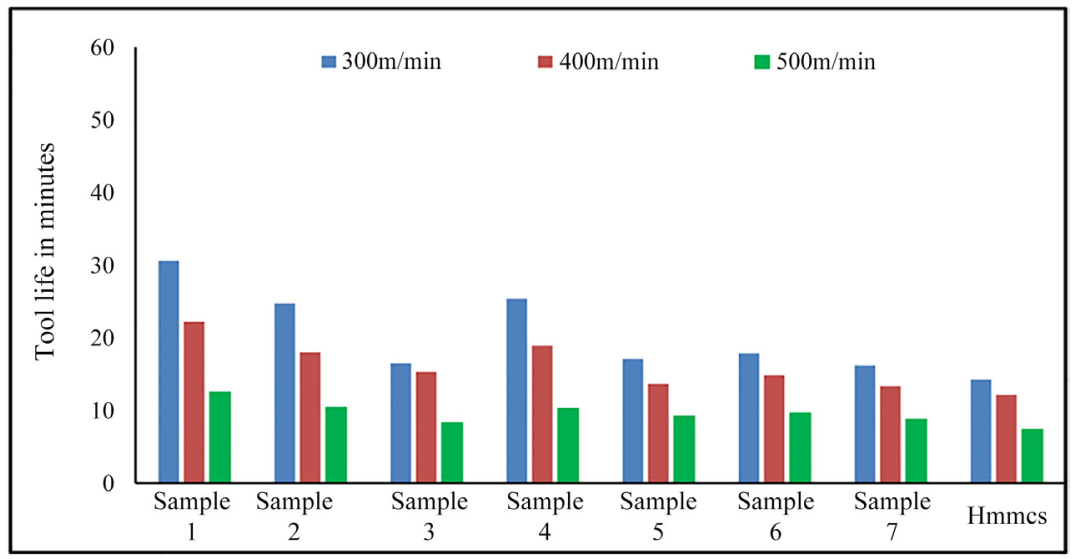

Figure 17. Effect of cutting speed on tool life using TiAlN coated carbide insert at $0.2 \mathrm{~mm} /$ revolution.

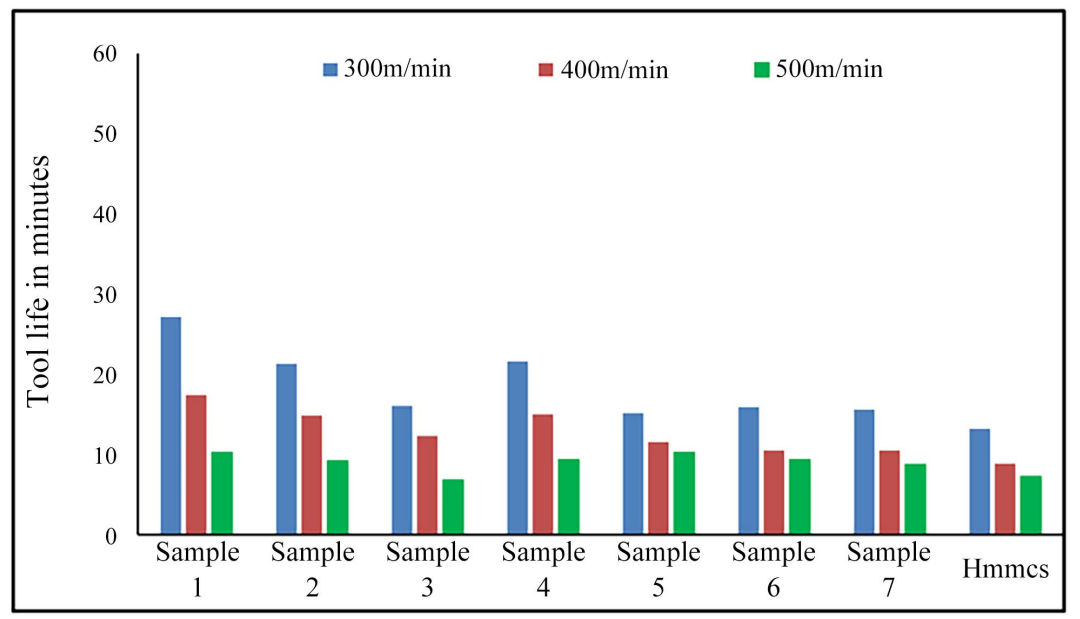

Figure 18. Effect of cutting speed on tool life using TiN coated carbide insert at $0.2 \mathrm{~mm} /$ revolution. 


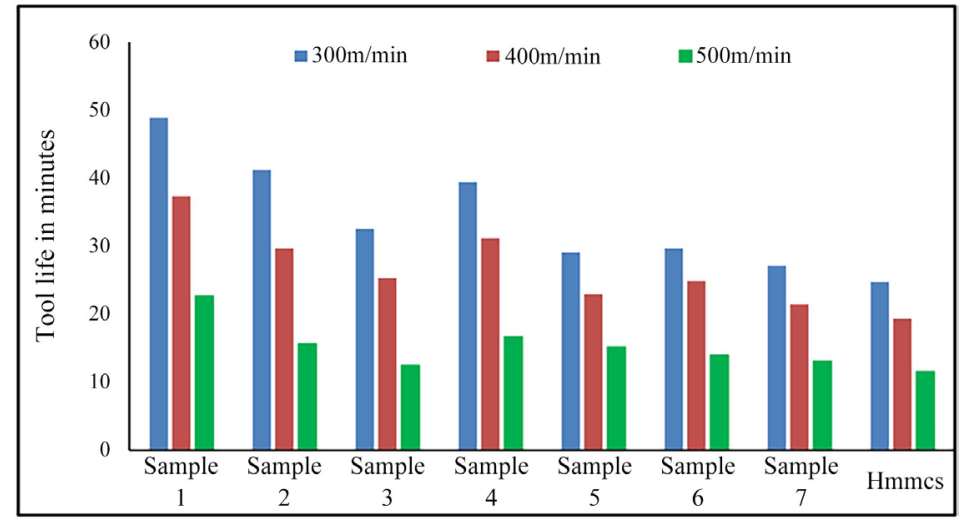

Figure 19. Effect of cutting speed on tool life using PCD insert at $0.2 \mathrm{~mm} /$ revolution.

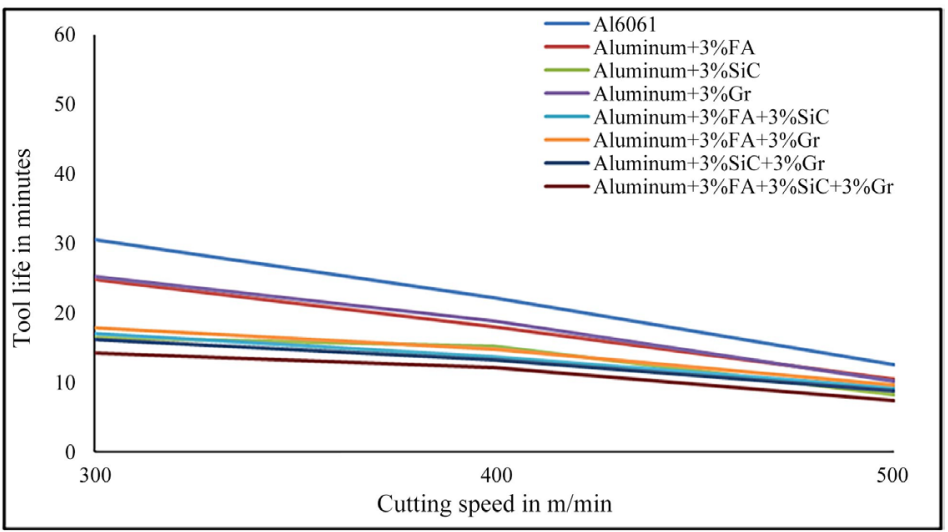

Figure 20. Effect of cutting speed and reinforcement on tool life-TiAlN coated insert at $0.2 \mathrm{~mm} /$ revolution.

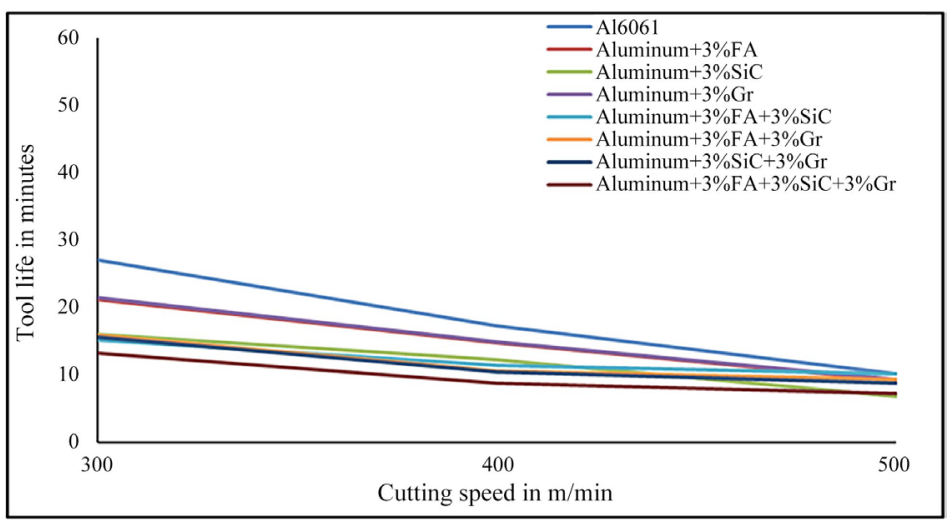

Figure 21. Effect of cutting speed and reinforcement on tool life-TiN coated insert at $0.2 \mathrm{~mm} /$ revolution.

From Figures 11-13, we can infer that as cutting speed increases the contact time of the insert reduces irrespective of the material used for turning at 0.1 $\mathrm{mm} /$ revolution feed. From Figures 11-13, it is also clear that, the tool life of the PCD inserts are higher than TiN and TiAlN coated carbide inserts irrespective of the material used for turning. However performance of the TiAlN coated carbide inserts found better than TiN coated carbide inserts. 


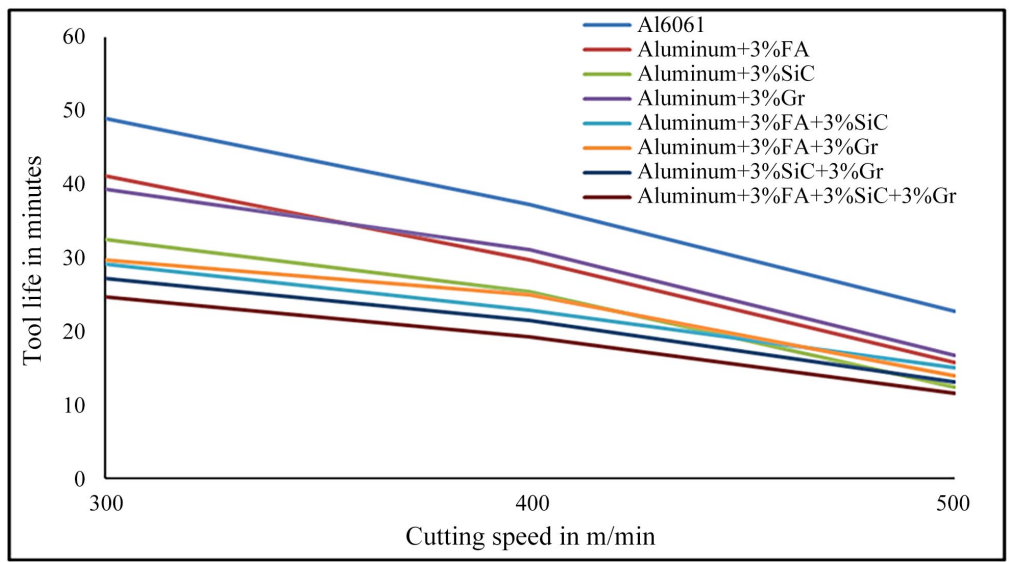

Figure 22. Effect of cutting speed and reinforcement on tool life-PCD insert at $0.2 \mathrm{~mm} /$ revolution.

From Figures 14-16, we can infer that while machining Al6061 castings the tool life was higher, irrespective of the cutting speed at $0.1 \mathrm{~mm} /$ revolution feed. When aluminum matrix reinforced with fly ash \& graphite particles, the tool life found better than aluminum matrix reinforced with Silicon carbide particles. From Figures 14-16, it is also clear that, the tool life of the PCD inserts are higher than TiN and TiAlN coated carbide inserts irrespective of the material and cutting speed used for turning. However performance of the TiAlN coated carbide inserts found better than TiN coated carbide inserts.

From Figures 17-19, we can infer that the tool life of the inserts during turning Al6061 and its composites as well as hybrid composite found lower irrespective of the material used for turning at $0.2 \mathrm{~mm} /$ revolution feed. From Figures 17-19, it is also clear that, the tool life of the PCD inserts are higher than TiN and TiAlN coated carbide inserts irrespective of the cutting speed used for turning. However performance of the TiAlN coated carbide inserts found better than TiN coated carbide inserts.

From Figures 20-22, we can infer that while machining Al6061 castings the tool life found higher, irrespective of the type of inserts used at $0.2 \mathrm{~mm} /$ revolution feed. When aluminum matrix reinforced with fly ash \& graphite particles, the tool life found better than aluminum matrix reinforced with Silicon carbide particles at $0.2 \mathrm{~mm} /$ revolution feed. The slope of cutting speed on tool life found almost linear in case of Hmmcs when uncoated carbide insert and PCD insert was used for machining. While machining Al6061 castings the tool life found high when compared to other combinations between $300 \mathrm{~m} / \mathrm{min}$ to $500 \mathrm{~m} / \mathrm{min}$ cutting speed. The contact time of inserts found lower while machining Hmmcs castings when compared to all the combinations of matrix and filler material, which indicates the wear resistance of the Hmmcs is higher.

\section{Conclusions}

Aluminum hybrid metal matrix composites containing 3\% FA, 3\% silicon carbide and 3\% graphite particles show higher wear resistance. From SEM micro- 
photographs it is evident that the average diameter of the reinforcements FA, $\mathrm{SiC}$, and Gr particles was measured below 53 microns. SEM analysis reveals that, the morphological details of the FA, silicon carbide, and graphite particles and also even distribution in the matrix. Good retention of fly ash, silicon carbide, graphite particles was observed in the SEM microphotograph. The hardness of the composite material having composition Al6061 + 3\% FA + 3\% SiC + 3\% graphite measured highest, this may be due to the reason that higher hardness of reinforcement content, that is $\mathrm{Al}_{2} \mathrm{O}_{3}, \mathrm{SiO}_{2}, \mathrm{Si}, \mathrm{C}$ and $\mathrm{Fe}_{2} \mathrm{O}_{3}$. The density of measured and theoretical values is almost aligned with each other. Thus demonstrate the characterization and the approach for the fabrication of the composite.

We can infer that as cutting speed increases the contact time of the insert reduces irrespective of the work material. We can conclude that as feed/revolution increases the contact time of the insert reduces irrespective of the work material. The contact time of inserts found lower while machining Hmmcs castings when compared to all the combinations of matrix and filler material, which indicates the wear resistance of the Hmmcs is higher. Built-up edge and built-up layer formation found high with matrix material when compared to Hmmcs containing $3 \%$ flyash, $3 \%$ silicon carbide and $3 \%$ graphite particle at all cutting speeds for identical machining conditions. At $500 \mathrm{~m} / \mathrm{min}$ cutting speed while machining Hmmcs material using PCD insert; the built-up edge formation was negligible.

\section{Conflicts of Interest}

The authors declare no conflicts of interest regarding the publication of this paper.

\section{References}

[1] Surappa, M.K. (2003) Aluminium Matrix Composites: Challenges and Opportunities. Sadhana, 28, 319-334. https://doi.org/10.1007/BF02717141

[2] Rohatagi, P.K., Weiss, D. and Gupta, N. (2006) Applications of Fly Ash in Synthesizing Low-Cost MMCs for Automotive and Other Applications. JOM, 58, 71-76. https://doi.org/10.1007/s11837-006-0232-4

[3] Dursan, T. and Soutis, C. (2014) Recent Developments in Advanced Aircraft Aluminium Alloys. Materials and Design, 56, 862-871. https://doi.org/10.1016/j.matdes.2013.12.002

[4] Jha, A.K., Sreekumar, K. and Sinha, P.P. (2010) Cracking of Aluminium Alloy Valve Body Used in Altitude Control of Satellite Launch Vehicle-A Metallurgical Investigation. Engineering Failure Analysis, 17, 1051-1061. https://doi.org/10.1016/j.engfailanal.2009.12.004

[5] Peters, M. and Leyens, C. Aerospace and Space Materials. Material Science and Engineering Vol. III.

[6] Auradi, V., Rajesh, G.L. and Kori, S.A. (2014) Preparation of and Evaluation of Mechanical Properties of $6061 \mathrm{Al}^{-} \mathrm{B}_{4} \mathrm{C}_{\mathrm{p}}$ Composites Produced via Two-Stage Melt Stirring. Materials and Manufacturing Processes, 29, 194-200. https://doi.org/10.1080/10426914.2014.892617 
[7] Hashim, J., Looney, L. and Hashmi, M.S.J. (1999) Metal Matrix Composites: Production by the Stir Casting Method. Journal of Materials Processing Technology, 92-93, 1-7. https://doi.org/10.1016/S0924-0136(99)00118-1

[8] Balasivanandha Prabhu, S., Karunamoorthy, L., Kathiresan, S. and Mohan, B. (2006) Influence of Stirring Speed and Stirring Time on Distribution of Particles in Cast Metal Matrix Composite. Journal of Materials Processing Technology, 171, 268-273. https://doi.org/10.1016/j.jmatprotec.2005.06.071

[9] Thomas, A.T., et al. (2014) Development of Feeding \& Stirring Mechanisms for Stir Casting of Aluminium Matrix Composites. Procedia Materials Science, 5, 1182-1191. https://doi.org/10.1016/j.mspro.2014.07.415

[10] Shanmughasundaram, P., Subramanian, R. and Prabhu, G. (2011) Some Studies on Aluminium-Fly Ash Composites Fabricated by Two Step Stir Casting Method. European Journal of Scientific Research, 63, 204-218.

[11] Mahendra, K.V. and Radhakrishna, K. (2007) Fabrication of Al-4.5\% Cu Alloy with Fly Ash Metal Matrix Momposites and Its Characterization. Materials Science-Poland, 25, 57-68.

[12] Palanikumar, K. and Karthikeyen, R. (2006) Optimal Machining Conditions for Turning of Particulate Metal Matrix Composites Using Taguchi and Response Surface Methodologies. Machining Science and Technology, 10, 417-433. https://doi.org/10.1080/10910340600996068

[13] Karthikeyen, R., Ganeshan, G., Nagarajan, R.S. and Pai, B.C. (2001) A Critical Study on Machining of Al-SiC Composites. Materials and Manufacturing Processes, 16, 47-60. https://doi.org/10.1081/AMP-100103696

[14] Ravi Kumar, D.V., Seenappa, C.R., et al. (2018) Corrosion Behavior of Cenosphere Reinforced Al7075 Metal Matrix Composite-An Experimental Approach. Journal of Minerals and Materials Characterization and Engineering, 6, 424-437. https://doi.org/10.4236/jmmce.2018.63030

[15] Singh, S., Kumar, S. and Kumar, S. (2015) Analysis of Chip Thickness Ratio While Machining of EN8D Steel. International Journal of Engineering Technology, Management and Applied Sciences, 3, 55-60.

[16] Bouzakis, K.D., et al. (2014) Effect of Cutting Edge Preparation of Coated Tools on Their Performance in Milling Various Materials. CIRP Journal of Manufacturing Science and Technology, 7, 264-273.

[17] Hung, N.P., Loh, N.L. and Xu, Z.M. (1996) Cumulative Tool Wear in Machining Metal Matrix Composites, Part II: Machinability. Journal of Materials Processing Technology, 58, 114-120. https://doi.org/10.1016/0924-0136(95)02115-9

[18] Narsimha, M. and Ramesh, S. (2014) Coating Performance on Carbide Inserts. International Journal of Engineering and Technical Research, 2, 175-179.

[19] Quigley, O., Monaghan, J. and Reilly, P.O. (1994) Factors Affecting the Machinability of an $\mathrm{Al} / \mathrm{SiC}$ Metal-Matrix Composite. Journal of Materials Processing Technology, 43, 21-36. https://doi.org/10.1016/0924-0136(94)90159-7

[20] Elangovan, R. and Ravikumar, M.M. (2014) Evaluation of Factors Affecting PCD Tool Wear Behaviour of Al-Flyash Metal Matrix Composites by Using Design of Experiments. International Journal of Mechanical \& Mechatronics Engineering, 14, 76-85.

[21] Elangovan, R. and Ravikumar, M.M. (2015) Performance of Al-Flyash Metal Matrix Composites. ARPN Journal of Engineering and Applied Sciences, 10, 1691-1696.

[22] Muthukrishnan, N. and Paulo Davim, J. (2011) An Investigation of the Effect of 
Work Piece Reinforcing Percentage on the Machinability of Al-SiC Metal Matrix Composites. Journal of Mechanical Engineering Research, 3, 15-24.

[23] Karakas, M.S., Acir, A., Ubeyli, M. and Ogel, B. (2006) Effect of Cutting Speed on Tool Performance in Milling of $\mathrm{B}_{4} \mathrm{C}_{\mathrm{p}}$ Reinforced Aluminum Metal Matrix Composites. Journal of Materials Processing Technology, 178, 241-246.

https://doi.org/10.1016/j.jmatprotec.2006.04.005

[24] Prasanth, K., Gopal, P.M., et al. (2018) Effect of Carbide Inserts with Titanium Nitride Coating of Different Thickness on Machining Mild Steel. International Journal of Chem Tech Research, 11, 23-28.

[25] Fathy, A., Abdelhameed, M. and Shehata, F. (2012) Effect of Some Manufacturing Parameters on Machining of Extruded $\mathrm{Al}-\mathrm{Al}_{2} \mathrm{O}_{3}$ Composites. International Scholarly Research Network, ISRN Materials Science, 2012, Article ID: 748734.

https://doi.org/10.5402/2012/748734 